\begin{tabular}{|l|l|l||}
\hline \multicolumn{2}{|c|}{ PublisherInfo } \\
\hline \hline PublisherName & $:$ & BioMed Central \\
\hline \hline PublisherLocation & $:$ & London \\
\hline \hline PublisherImprintName & $:$ & BioMed Central \\
\hline \hline
\end{tabular}

\title{
Generating robustness
}

\begin{tabular}{|l|l|l||}
\hline \multicolumn{2}{|c|}{ ArticleInfo } \\
\hline \hline ArticleID & $:$ & 4672 \\
\hline \hline ArticleDOI & $:$ & $10.1186 /$ gb-spotlight-20030108-02 \\
\hline \hline ArticleCitationID & $:$ & spotlight-20030108-02 \\
\hline \hline ArticleSequenceNumber & $:$ & 24 \\
\hline \hline ArticleCategory & $:$ & Research news \\
\hline ArticleFirstPage & $:$ & 1 \\
\hline \hline ArticleLastPage & $:$ & 2 \\
\hline \hline & & RegistrationDate : 2003-1-8 \\
\hline ArticleHistory & $:$ & OnlineDate \\
\hline \hline ArticleCopyright & $:$ & BioMed Central Ltd2003-1-8 \\
\hline \hline ArticleGrants & $:$ & \\
\hline \hline ArticleContext & $:$ & 130594411 \\
\hline \hline
\end{tabular}




\section{Jonathan B Weitzman}

Email: jonathanweitzman@hotmail.com

Gene knockouts often fail to reveal phenotypes, suggesting that biological systems are laden with compensation mechanisms, which might involve functional redundancy between duplicated genes or between alternative pathways and networks. In the January 2 Nature Gu et al. describe a genome-wide evaluation of genetic robustness against null mutation (Nature 2003, 421:63-66). Analysis of fitness measurements for nearly all single-gene deletion mutants in the yeast Saccharomyces cerevisiae showed that duplicate genes were less often associated with lethal phenotypes. Deletion of duplicate genes had similar fitness effects. Gu et al. found evidence for a correlation between the sequence similarity of the duplicates and the frequency of compensation. Furthermore, deleting the gene copy that is most highly expressed had the greatest effect on fitness. Functional compensation between duplicate genes may account for a quarter of gene deletions that lack phenotypes.

\section{References}

1. Nature, [http://www.nature.com]

2. Systematic screen for human disease genes in yeast. 